\title{
Living Costs and Living Standards: Australian Development 1820-1870
}

\author{
Laura Panza (Melbourne) \\ Jeffrey G. Williamson (Harvard and Wisconsin)
}

\begin{abstract}
This paper contributes to the New World living standard leadership debate by comparing the Australian experience during 1820s-1870s with the US, Latin America, and the UK. Using novel living costs data we compute two estimates of income leadership: welfare ratios and PPPadjusted GDP per capita. Australia started considerably below the UK and the US but by the 1870s it had overtaken the former and had almost done so for the latter, due to relatively rapid labor productivity growth and a steep decline in living costs. Still, in the 1870s Australia was not the world income leader, but a close second.
\end{abstract}

Keywords: Colonial Australia, cost of living, real incomes, living standard leadership, growth

JEL: N17, N37, O47, O56

Laura Panza

University of Melbourne

laura.panza@unimelb.edu.au

\author{
Jeffrey G. Williamson \\ Harvard and Wisconsin Universities \\ jwilliam@fas.harvard.edu
}

\footnotetext{
${ }^{1}$ Previous working papers leading up to this one have benefitted greatly from the comments of William Coleman, Peter Lindert, Ian McLean, David Merrett, Deborah Oxley, Martin Shanahan, Andrew Seltzer, Hamish MaxwellStewart, and especially Jeff Borland. An earlier version of this paper was presented at a University of Essex conference (June 26-27 2017) celebrating the career of Timothy J. Hatton. We are grateful for the useful comments of three anonymous referees which improved the paper.
} 
"Perhaps the single economic "fact" about Australia most widely known among economists and economic historians outside the country is that for some period during the latter half of the nineteenth century it appears to have recorded the world's highest standard of living".

McLean, 2012, p.11

\section{The Issues}

In a 2017 working paper, the present authors revisited the extensive literature dealing with the question "was Australia the richest in the late nineteenth century?" A literature with a long tradition, starting with Michael Mulhall who more than a century ago estimated that Australian 1891 per capita income (in £ sterling) was 3.1 percent above the United States and 19.3 percent above the United Kingdom (Mulhall 1892, p. 320). Since then, there has been an improvement in the quality of the estimates (N. Butlin 1970; Bairoch 1976; Sinclair 2009; M. Butlin et al. 2015), including showing how high prices of non-tradables resulted from the Balassa-Samuelson effect. That is, countries with high labour productivity growth - like Australia between 1820 and $1870-$ also experience high wage growth. The Balassa-Samuelson effect implies that an increase in wages driven by productivity growth in the tradable goods sector (mainly wool and mineral products in nineteenth century Australia) will also lead to higher wages in the non-tradable service and food-producing sectors. Since tradable goods prices are determined in world markets, the relative price of non-tradables rises. Since the non-tradable consumption share was large everywhere in the nineteenth century, all New World settler countries had high living costs compared to Western Europe. 
But why might Australian living costs have been even higher than its competitors, like North America? Because early nineteenth century Australia experienced not only high and rising living costs (as implied by the Balassa-Samuelson effect), it also faced high prices for flour, grain, cheese and other imported foods, which, due to its relative isolation, persisted until the mid-nineteenth century. Thereafter the globalisation of world markets offset the BalassaSamuelson forces, and by the 1870s had reduced Australia's high living costs relative to its New World competition and to Britain.

The economic leadership literature has also shown that purchasing-power-parity (PPP) assessments reduce the Australian 1891 lead at least over the United Kingdom (Haig 1989; Allen 1994; Thomas 1995). A recent article by Brian Haig (2008), which responds to Stephen Broadberry and Douglas Irwin's (2007) comparative study on the British ${ }^{2}$ and Australian economies, has revived the debate regarding the extent of Australia's living standard lead. Thus, it has called back into question the measurement of Australian income and living standards relative to other countries, especially those in the New World.

This paper contributes to this debate by comparing the Australian experience with that of other countries between the 1820 s and the 1870 s, particularly with the United States, the young republics in Latin America, and the United Kingdom. We do so by replacing Angus Maddison's income per capita data (Maddison 1995a, 1995b), data which Ian McLean used to report that "Australian incomes averaged 51 percent above American incomes" in the 1870s and 1880s and “about 45 percent higher in 1870/71" (McLean 2007, p. 638). In a previous working paper, we used the Maddison-McLean 1870/71 45 percent estimate as a benchmark. We thought that

\footnotetext{
${ }^{2}$ Allow us poetic license in this paper. Our comparisons are always with the United Kingdom, but we more frequently refer to Britain and Great Britain in the text.
} 
McLean's comparison might have been inappropriate for two reasons. As McLean himself pointed out, confining the comparisons to national boundaries can be misleading (McLean 2012, p.13). In fact, American regions differed radically in per capita incomes in 1870 , making their aggregation problematic in any Australian-US comparison. First, they included a recently slavebased poor American South, which had been destroyed by the Civil War. Second, the relative weight and size of Australia's and America's mining states differed profoundly, especially after their gold (and silver) booms. In fact, mineral-rich Victoria accounted for 46.5 percent of Australia's 1861 population while the mineral-rich American West represented only 2 percent of the 1860 US population. Thus, we wondered what would happen to the GDP per capita comparison when we excluded those mining-dominated regions, the slave-based and relatively poor US South, and made the comparison in 1860/61 before the Civil War. We concluded from this exercise that the income per capita gap favoring Australia in 1871 was reduced by ignoring the mineral-rich regions in both countries, and also by ignoring the American South which was so badly damaged by the Civil War. Even so, Australia's Maddison-estimated GDP per capita leadership persisted.

This paper raises another, more serious, issue. Are we happy with Maddison's 1870/71 benchmark? No: we are not. We are confident that, based on recent research on other countries and epochs (Prados de la Escosura 2000; Lindert and Williamson 2016; Lindert 2017), Maddison's back-casting from modern-day PPPs generated misleading conclusions about levels of GDP per capita in the past, and that the use of an 1870s country-specific PPP would reduce the Australian advantage over its competitors from the Maddison-McLean 45 percent estimate, as it does for 1891. We also thought that the PPP adjustments would be even more pronounced for the decades before the 1870 s when world commodity market integration was much weaker. 
Our suspicions about Maddison's estimates are reinforced by other evidence. A Human Development Index (Shanahan 2015: Table 22.3, p. 501) places Australia only 2 percent over the US in 1871 ( 0.516 vs 0.506$)$ and only 3 percent over the UK (0.516 vs 0.500$)$. A "short cut" PPP-adjusted GDP per capita estimate (Prados de la Escosura 2000: Table 9, p. 24), discussed below, has Australia at 30.4 percent greater than the US, while Maddison (1995a, 1995b) had it at 74.1 percent $^{\text {greater. }}{ }^{3}$

Thus, our agenda in the next section is to make the assessment of relative incomes by estimating comparative living standards computing common working class market baskets using prices of goods in each country and colony in the same year to a common working class market basket. How much did country-specific relative prices matter, especially in comparing the landabundant New World with the land-scarce Old World, and especially before late nineteenth century globalisation had caused so much commodity price convergence between countries? We make our estimates by decade - from the 1820 s to the 1870 s - thus to identify the timing of catching up with and overtaking the competition. ${ }^{4}$

In Sections 3 and 4, we then explore Australian PPP-adjusted GDP per capita relative to its main competitors, the United States and the United Kingdom, using the PPP-deflators implied by our living standard estimates. Even if both measures get the prices right, the two measures can still differ for five reasons. First, and perhaps most important, the relative living standard estimates are for working class employees themselves or for a standard family of four, and we know the 1820 s were dominated by single men while the 1870 s were dominated (like the US and

\footnotetext{
${ }^{3}$ See Table 2 below.

${ }^{4}$ We use decade averages since, like all commodity exporters (Williamson 2012), Australia exhibited very volatile wages, prices, and incomes across seasons and years.
} 
UK) by families, implying that over time Australian men chose to share their purchasing power with women and children. Second, the relative standard of living estimates are for towns only, while the GDP estimates are, of course, for aggregate activity. Third, the living standard estimates are for urban common labour, thus ignoring those working in mines, factories, farms, and service sector jobs, plus ignoring white collar employees as well as those who hired all of them. Fourth, the working class market baskets exclude services (but include house rents) while more than half of GDP (52 percent in 1850: M. Butlin et al. 2015: Table A1, p. 556) were services, although much of it was intermediates and not final consumption items (like government services, retail and wholesale trades, transportation and utilities). And fifth, there are likely to be errors in both. Finally, where the data allow, our standard of living estimates are reported by colony thus to speak to issues of regional inequality, divergence and colonial reversals of fortune. Our key findings suggest that existing estimates of Australia's GDP overstate the country's living standards. Beyond the reasons highlighted above on the discrepancies between PPP-adjusted GDP estimates and welfare ratios, we stress the importance played by the large share of non-tradables in workers' consumption baskets throughout the New World before 1870, a fact which raised living costs and lowered its relative purchasing power via the Balassa-Samuelson effect discussed at length above.

\section{Constructing and Interpreting the New Living Standard Estimates}

We construct our Australian living standards between the 1820s and the 1870s according to the method proposed by Robert Allen et al. (2001), which enables us to estimate the relative purchasing power of an average Australian working class household. This methodology, widely used by economic historians (see for example Lindert and Williamson 2016, Allen et al. 2012, and Arroyo Abad et al. 2012), has the advantage of allowing international comparisons 
measuring the relative purchase capacity of local wages. We choose this direct methodology over the alternative based on indirect Maddison-like backward projections, in order not to rely on the implausible assumption that consumption patterns and relative prices today are similar to those of the early and mid nineteenth century. ${ }^{5}$ Importantly, this methodology allows us to account for the role of non-tradables, items which represented a large share of the consumption basket for an average Australian wage earner and his household before the first globalisation wave, hence providing more accurate estimates of living standards. Indeed, as most consumer staples were not traded over great distances, ${ }^{6}$ their prices reflected domestic relative factor endowment in Australia. Relative land abundance made some foods, like meat and potatoes, and fuel cheaper than in the Old World, thus providing an advantage in terms of purchasing power. On the other hand, relative labour scarcity implied more expensive labour-intensive manufactured goods, such as clothing, candles and soap, thus eroding such advantages. ${ }^{7}$ They were further eroded, or even overturned, by the "tyranny of distance" ${ }^{\prime 8}$ which meant that commonly consumed colonial imports such as sugar, tea, rum, cheese, and even flour, were very expensive. Finally, through the Balassa-Samuelson effect, labour scarcity generated high house rents.

Following Allen's approach, we first calculate the annual expenditure of a working man based on a food basket that included the minimum calories needed for subsistence (a mix of

\footnotetext{
${ }^{5}$ See Panza and Williamson (2017) and Lindert (2017) for a more detailed discussion.

${ }^{6}$ Of course, the colonies did trade low-quality colonial cheese, peas, beans, potatoes and other foodstuffs with each other, but not with the much-more-distant rest of the world.

${ }^{7}$ A factor endowment driven by huge land/labour ratios produced labour scarcity, high wages, and high costs of labour-intensive local manufactures. Furthermore, small-scale production for small local markets insured relatively low manufacturing labour productivity as well.

${ }^{8}$ This phrase is taken from the title of Geoffrey Blainey's famous (1966) book.
} 
proteins, carbohydrates and fats summing up to 1,935 kilocalories), and on other essential requirements such as clothing (linen and cotton cloth), heating and cooking fuels (wood converted into BTUs), lighting (lamp oil) and house rent (see Table 1). The resulting one-person basket, called the "bare-bones" basket, is then turned into that of an average working class family to account for the needs of a couple with two children. Under the assumption that married women and their children were not income earners, ${ }^{9}$ this expenditure is then used as a deflator of average annual earnings of an urban unskilled worker and his family, thus allowing for PPP comparison across countries for similar jobs and household composition. In addition to this barebones basket, embodying living standards at subsistence levels, we computed a more diversified and expensive one, allowing for more comfortable living conditions, called the "respectable" basket (equivalent to 2,421 kilocalories, more than 25 percent more than the bare-bones basket, and with a higher content of clothing (up 167 percent), soap, fuel and light (all three doubled): see Table 1). The deflated annual earnings estimates generate what are called bare-bones and respectable welfare ratios, that measure how many consumption baskets a household could buy, and thus their welfare levels.

For the construction of a household's expenditure for each decade and colony, we first adjusted the basket to mirror the consumption patterns of a typical Australian family in the midnineteenth century. Specifically, as illustrated in Table 1, we used potatoes and meat as the main staple foods. These are coupled with wheaten flour (bare-bone only) and bread (respectable

\footnotetext{
${ }^{9}$ Married women did work on farms and sheep stations where their husbands were employed as farm labour, but this was uncommon in the towns where our earnings data are taken.
} 
only), beans, butter, cheese (respectable only), and rum (respectable only). Soap, linen, candles, lamp oil, fuel and rent constituted the remainder of the working class household's expenditures. ${ }^{10}$

Our price and wage data come from a largely underexploited parliamentary source: The Statistical Tables relating to the Colonial and other Possessions of the United Kingdom (18501900). We complement this source for the pre-1850 years by the impressive and detailed occupational wage and commodity price data reported in Timothy Coghlan's Labour and Industry in Australia (1918) and James Barnard's Statistical account of Van Diemen's Land (1856). We infer annual incomes for unskilled urban workers receiving a daily wage, by assuming that a year consisted of 250 working days for those not on weekly contracts and thus taking employment by the day. ${ }^{11}$ All data, which are available by month and even week, are averaged over the year, but we report them here as decade averages.

\footnotetext{
${ }^{10}$ See Panza and Williamson (2017) for further details on the construction of the basket.

11 The 250 figure is commonly assumed in living standard calculations for other regions and times, assuring comparability with Australian estimates in this study. There is a large literature on nineteenth century US and
} Britain that supports this working days assumption for urban common labour in Australia. On the US experience, see Lebergott (1964). Most urban common labourers worked on day rates. According to Baxter (1868, pp. 46-9), the British working class in the 1860 s worked 10-20 percent less than full-time. The 20 percent applied to "casual" employment as common labour, navies, wharf labourers, and pick, shovel, and carting workers on construction sites. The 10 percent referred to skilled in the building trades, metal trades, artisans, and other skilled workers. Writing a half century later, Bowley (1919, pp. 28-30) agreed with Baxter. An excellent and comprehensive survey can be found in Boyer (2016, pp. 3-12). Lindert and Williamson (2016) argue the same when constructing their social tables for the United States in $1774,1800,1850$, and 1860 . It seems to us that there is little reason to expect that the Australian working class was any different. Thus, taking a full-time year as 313 days (with only Sunday at rest), we estimate the following: Baxter's 20 percent $=0.2 * 313=62.6$ implying about 250 actual days worked per year for unskilled common labour on daily rates. See Panza and Williamson (2017) for those citations. 
Working class house rents in Australia's colonial towns are remarkably well documented (along with descriptions of the number of rooms, kitchen availability, water source, sewage and distance from the central district). These rents are reported in various volumes of Coghlan (1918): Sydney 1830s (I: 286-7); 1840s (I: 467); 1850s (II: 792-3); 1860s (II: 1105); 1870s (III: 1626-9): Melbourne 1850s (II: 1802-13); 1860s (II: 1813); 1870s (III: 1627-9); Adelaide 1840s (II: 820); 1850s (II: 1820-2); 1860s (II: 1127-8); and 1870s (II: 1629); Hobart 1870s (III: 1628); and Brisbane 1860s (II: 1120). These are used in Table 2, and where Australian city/decade observations are missing, we assume rents were 5 percent of total working class expenditures (a common assumption in the literature on other countries). Rents were higher in Sydney than in other colonial towns (except Brisbane and other Queensland towns), and higher than "in English towns of similar size" (Coghlan 1918: I: 467). They were relatively low in Hobart compared with other colonial towns (Coghlan 1918: III, 1628).

Our sources also report payment arrangements for farm labour, domestic servants, shepherds, and line riders. These were almost always (until the 1850s) for an annual contract and the payment was usually made in kind as rations, clothing, and huts for shelter. However, we do not use these data and for two reasons. First, the foreign regions with which we want to make living standard comparisons also typically use urban common labour, not farm labour. Second, we have not been able to find any evidence that can be used to price these in-kind items. There is plenty of qualitative evidence that those prices were very high for all commodities carted from town to the interior (pretty much everything but meat). In addition, housing (often just huts) was of much lower quality for farm labour, shepherds and stockmen. Thus, in this paper we stick with the town wage and price data where the documentation is extensive. 
While data for the 1820 s, 1830 s, and 1840 s are available only for New South Wales ${ }^{12}$ and Tasmania, we can calculate living standards for all six colonies except Queensland for the remaining decades. ${ }^{13}$ The welfare ratios are presented in Table 2 and Figures $1 \mathrm{~A}$ and $1 \mathrm{~B}$. These ratios were very similar in New South Wales and Tasmania during the 1820s, but then a gap opened up in the 1830 s - with the former's living standards continuing to improve, while the latter fell behind (34 percent behind New South Wales) - thus signaling the beginning of a process of regional divergence still visible today. ${ }^{14}$ New South Wales and Victoria were the best performers, South Australia was catching up, while the more newly-settled Western Australia brought up the rear.

Table 2 also compares Australia's urban living standards with those of London, Boston, Philadelphia, and of some towns in the new Latin American republics. The table does not include New Zealand, despite being arguably the most natural country to use for comparison, since both

\footnotetext{
${ }^{12}$ New South Wales included the Port Philip District in which Melbourne eventually emerged. The area became Victoria when it separated from New South Wales in 1851.

${ }^{13}$ The Statistical Tables (1850) provide data for wages in Queensland but not prices. Wage and price data for Victoria start in 1860, after it had separated from New South Wales.

${ }^{14}$ The Tasmanian decline was dramatic in the 1840 s, largely due to a change in British convict transport policy, ceasing their export to New South Wales and dumping them all in Tasmania. This labour supply shock clearly helps explain lagging Tasmanian living standards in the 1840s (23 percent behind New South Wales by the 1850s). It might also be explained by its distance from the gold fields in Victoria. But these two forces cannot explain the persistence of this reversal of fortune after Britain stopped the convict export even to Tasmania and after the mining booms turned to bust (see Reynolds, 2012). Cashin (1995b, p. 28) reports regional divergence between Tasmania and the rest of Australia, but his GDP per capita estimates start only at the end of our period, 1861 and 1871. Moreover, Cashin (1995a) finds an increase in the dispersion of real per capita GDP among the Australian colonies for the periods 1861-1871, 1901-1921 and 1947-1951.
} 
British possessions were influenced by similar patterns of international trade, migration, and productivity growth (Greasley and Oxley, 2000, 2004 and 2005). The problem is simply that price and wage data across the Tasman Sea only start becoming available in the 1870s. Based on the real wage comparisons presented by David Greasley and Les Oxley we know that New Zealand was far behind Australia in the early 1870s, the former's real wages being only 73 percent of the latter (Greasley and Oxley 2004, Figure 1, p. 35). This gap was not filled by the end of the long nineteenth century, as urban common labour living standards did not converge (Greasley and Oxley 2004, pp. 27-8). ${ }^{15}$

The data in Table 2 suggest that in the 1820s Australian towns enjoyed higher living standards than all Latin American cities except Buenos Aires (3.28 versus 2.62). Furthermore, living standards in Sydney (2.61) and Hobart (2.64) were way below those of Boston (6.03), Philadelphia (8.95), and even London (3.64). ${ }^{16}$ The living standard advantage of the United States and Britain was gradually eroded in the following decades. Australia was 65 percent lower than the United States in the 1820 s and 28 percent behind in the 1870 s - strong convergence. It was 28 percent behind Britain in the 1820 s but 19 percent ahead in the $1870 \mathrm{~s}$ - an overtake. Thus, our estimates suggest that, despite living comfortably, the Australian working man did not become the world's richest by the 1870 s, contrary to the existing narrative and to Maddison-

\footnotetext{
${ }^{15}$ While Greasley and Oxley's findings reject the existence of any trans-Tasman Sea wage convergence for nonfarm common labourers, their empirical analysis points to the existence of a common stochastic trend between the two wage series, thus suggesting that common shocks influenced wage movements similarly in both countries.

${ }^{16}$ While the four-member-family assumption ensures that comparisons between countries and times standardize family size, it may understate average Australian living standards in the 1820 s and 1830 s since, given male dominance, families were less numerous and single person households more common. Family size information for this period is scarce, so we are unable to quantify the magnitude of the underestimation.
} 
McLean assumptions. In fact, using this direct approach to compute living standards yields somewhat different results relative to available aggregate measures based on Maddison-like back-casting. Specifically, the trends in our PPP-based estimates differ from the international GDP per capita comparison proposed recently by Madsen (2015, pp. 36-37), which places Australia as the richest economy from 1800 onwards, above all other settler colonies and the UK. To summarize Table 2 and taking London equal to unity, in the 1870s living standards in Sydney were 1.26, Melbourne 1.23, Adelaide 1.03, Hobart 0.9, and Perth 0.7. Australia's two richest cities, Sydney and Melbourne, were only 66 and 64 percent of the average of Boston and Philadelphia.

This evidence suggests that Australian workers were not the "richest" in the 1870 s or before. They may have been "rich" by European and Latin American standards, but the United States was the clear world leader, despite the Civil War damage of the 1860s. The explanations for this finding, confirmed when using PPP-adjusted GDP per capita, are explored in detail below, but they lie with high living costs. Here we simply highlight the role played by non-tradables: a large portion of the subsistence goods included in the Allen basket were not traded (particularly before the 1870s) and made up more than half of the consumption basket throughout our half century (see Table 7). Australian labour scarcity bid up wage rates, raising relative prices of non tradables. In addition, Australia's geographic isolation led to high transport costs, especially until the first wave of globalisation, so that imports were also expensive. These two forces reduced workers' purchasing power.

Living standards were not uniform across Australian colonies. Table 3 illustrates the drivers of such differences by decomposing the welfare ratios between annual income and cost of the consumption basket (expressed in shillings). Data for the 1820s-1840s are only available for 
Tasmania and New South Wales. They show that while the cost of the basket remained stable in the 1820 s and 1830 s for both colonies, annual earnings declined in Tasmania, thus setting in motion a process of regional divergence. This continued until 1870, despite a short-lived catch up in the 1840s. Overall, nominal income growth was slower than cost of living increases for Tasmania throughout our period: living costs in Australia were highest there in the 1850s and 1860s, while nominal earnings were lowest in the 1860s and 1870s. Similarly, Western Australia lagged behind due to its high costs of livings (the highest in the 1860s and 1870s). In contrast, annual income increases in Victoria and New South Wales exceed cost of living increases. Among the "peripheral" Australian economies, the South Australian experience stands out: its living standards were relatively higher than Tasmania and Western Australia mainly due to its lower living costs.

\section{Welfare Ratios versus PPP-Adjusted GDP Per Capita}

This section compares two measures of Australian living standards 1820-1870: welfare ratios for an urban working class household and PPP-adjusted GDP per capita estimates, that is, for the average Australian. The latter is constructed by deflating each colony's nominal GDP per capita $^{17}$ (New South Wales only until 1840) by a price deflator derived from our bare-bones cost of living estimates. We then generate an Australia-wide real GDP per capita measure by computing a population-weighted average. Table 4 (columns 1 and 3) shows that the two measures tell slightly different stories about the evolution of Australian living standards. For instance, the GDP per capita estimates point to much faster growth in the 1830 s and 1860 s

\footnotetext{
${ }^{17}$ We use a standard source here, Sinclair (2009), as do so many other Australian scholars, including Magee et al. (2016) in their 1861-1909 comparison of real GDP per capita between South Africa and Australia. Sinclair's data suffer the same PPP shortcomings as does Maddison's.
} 
compared with the welfare ratios; they also show a fall in real incomes in the 1840 s, reflecting the depression of 1840-2 and the slow recovery in the years following.

We can identify several possible explanations for such differences in the two living standard measures. First, we need to stress the different numerators used, real annual earnings of unskilled urban working class households versus GDP per capita: the former relates to only one type of worker, while the latter includes all other earnings categories such as miners, farm labours, shepherds, skilled in the building trades, and white collar employees, firm profits and property incomes. In this sense, the decades where we find higher living standards using PPPadjusted GDP per capita signal that the real income of unskilled urban common labour was improving at a slower pace relative to the rest of the economy. This was certainly the case during the 1850s mining boom and undoubtedly the Balassa-Samuelson effect also contributed to it.

Second, the welfare ratios provide income estimates only for urban households while PPP-adjusted GDP per capita also includes rural households. Pastoralism, farming and mining were the driving forces of Australia's growth, particularly from the 1850s as the economy started becoming progressively more integrated into global markets (Greasley 2015). This helps explain the faster growth observed by using real GDP per capita relative to the welfare ratios: the former increased by 142 percent between the 1850s and the 1870 s, while the latter by 68 percent. Third, the only component of the service sector included in the working class market baskets used to construct the welfare ratios is house rents, while, as we have pointed out above, more than half of Australia's GDP were services (52 percent in 1850: M. Butlin et al. 2015: Table A1, p. 556). Again, this suggests that the service sector was growing faster than manufacturing, a trend related to the role of the pastoral economy highlighted above. In fact, the growth of the wool industry created a backward-linkage demand for supporting services to facilitate its production, 
transport to ports, financing, and marketing. From the 1850 s onwards, a sustained growth of the service sector, such as construction, financial institutions, large mutual insurers and banks (Keneley 2014, pp. 375-77).

Fourth, it is likely that the decline and disappearance of coerced labour played a role. In fact, the welfare ratios reported in Table 2 refer to free worker households, while the GDP per capita estimates include convicts under the assignment system. Working convicts represented around 56 percent of Australia's labour force in 1830 and around 36 percent in $1840 .{ }^{18}$ It is what was called "assigned" convict labour that matters here (in 1827, 72 percent were assigned, and in 1835 the figure was 66 percent: Coghlan 1918 vol. 1, pp. 180-181). The rest of the convicts were employed on public works or incarcerated. The assignment system was introduced to encourage private sector development by having convicts hired out or "assigned" to private employers. ${ }^{19}$ Indeed, the assignment system was introduced to reduce labour scarcity in the private sector, to lower the financial burden on the colonial public purse and to encourage free migration to Australia (see, for example, Coghlan 1918. vol. 1: Pt. II, Ch. II; Butlin 1994: pp. 46-55; Meredith and Oxley 2015). Specifically, the system assigned non-violent convicts to work for private sector masters at all skill levels and occupations. The colonial government published requirements about in-kind "payments" under the system, making it possible for us to assess the value of their in-kind "earnings." These included (New South Wales, 1836: Coghlan 1918, vol. I, p. 182): a weekly ration of $9 \mathrm{lbs}$. of flour, $7 \mathrm{lbs}$. of beef or mutton, $2 \mathrm{oz}$. of salt, and $2 \mathrm{oz}$. of soap;

\footnotetext{
${ }^{18}$ See footnote 7 in Panza and Williamson (2017) on the construction of convict labour force participation shares.

${ }^{19}$ The year 1821 marks the colonial government's decision to give priority to the private (over public) employment of convicts. For a comprehensive and well-informed summary of the convict system in the 1820 s, 1830 s, and early 1840s, see Coghlan (1918, vol. I: pp. 173-99.
} 
plus a yearly allotment of 2 jackets, 3 shirts, 2 pairs of pants, 3 pairs of shoes, a hat, a blanket, and a mattress. Some were allowed to work extra hours after-3pm. Typically, only mechanics and domestics received cash payment for that after hours work, while others were given more rations, clothing, rum and other items for the extra work. Assuming convicts got those after-3pm extras, the assigned convicts earned only around 59 percent of free labour's income (Panza and Williamson 2017). If they did not, then the figure would be much lower.

Table 4 (column 2) reports a labour force weighted "average" welfare ratio, encompassing both convicts and free. ${ }^{20}$ The resulting "average" living standards are lower for the 1820 s-1840s period, ${ }^{21}$ after which the convicts previously transported were "emancipated" (that is served their time) and the transportation system itself came to an end. Consequently, accounting for coerced labour yields a faster growth rate of the welfare ratio between the $1820 \mathrm{~s}$ and the 1870s (a 191 percent increase rather than a 129 percent increase), albeit still slower than the growth of the GDP per capita estimates (a 233 per cent increase), but closer.

Fifth, the welfare ratio estimates are for a standard family of four, while we know that due to the high gender imbalance characterizing the convict and free labour inflow to the Australian settler economy, households in the 1820 s were dominated by single men, while the 1870s were dominated by families. This implies that over time Australian men chose to share their purchasing power with women and children. On the other hand, the deflator of our PPPadjusted GDP per capita measure accounts only for one person's expenditure and as such does

\footnotetext{
${ }^{20}$ The share of convicts in the labour force was 57 per cent in the 1820 s, 51 percent in the 1830 s and 18 per cent in the 1840 , dropping to almost zero in the 1850 s.

${ }^{21}$ They would be even lower, and growth rates across the half century even faster, if we assumed instead that the average assigned convict did not receive the after-hours extras.
} 
not capture the demographically-induced change in preferences and expenditure patterns. This fifth issue needs elaboration.

When analyzing nineteenth century Australia's growth it is important to assess the impact of changes in the labour participation rate, and in some other settler economies as well, but not in the United States. We will have more to say about this in a moment, but note here that the last two columns of Table 4 report the growth performance in our PPP-adjusted GDP per capita and per worker (including both male and female labour). Over the five decade, the per capita annual growth rate was 1.3 percent and the per worker rate 2.4 percent. By the standards of the early nineteenth century, this was a very rapid per capita growth rate, much faster than Britain and Western Europe, while about equal to the United States (Lindert and Williamson 2016: Tables 5.3 and 5.4, pp. 102 and 104). But the growth rate of GDP per worker was a catch up rate in terms of a worker's earnings capacity. Thus, the fall in the labour participation rate mattered to Australia. Between the 1820 s and the 1870 s, the labour participation rate dropped from 61.5 to 40 percent reflecting an enormous fall in the adult male population share and a related drop in the male/female ratio from 3.2 in 1828 to 1.2 in 1871 (Seltzer 2015: Table 8.2, p. 180). Therefore, it is informative to make a comparison between GDP per capita and per worker, reported in columns 3 and 4 of Table 4 . As we have seen, the latter rose much faster than the growth rates of GDP per capita, consistent with the drop in labour force participation.

\section{Living Costs and the Real Income Leadership Debate}

We can now use our real GDP per capita estimates to place Australia's experience in a comparative perspective, by relating its purchasing power per capita with those in America and Britain. This is not the first time such an assessment has been made for 1820-1870 Australia, but 
it is the first time that current Australian prices have been used to do so. Maddison's (1995a, 1995b) estimates are well known and used extensively in comparative studies. However, we now know how questionable are such estimates based as they are on 1990 (or even more modern) purchasing power parity (Prados de la Escosura 2000; Lindert and Williamson 2016; Lindert 2017). ${ }^{22}$ Almost two decades ago, Prados de la Escosura offered what he called a "short cut" method of capturing the impact of changing relative prices over the long run. His "short cut" method was used to derive current period PPP-adjusted GDP per capita. While his "short cut" is certainly to be preferred over those using modern day relative prices, it is still only a "short cut."

Table 5 reports all three estimates. This study's estimates confirm the welfare ratios key findings: Australia started with a lower purchasing power than Britain and the United States in the 1820 s and its living standards improved up through the 1830 s, although only from the 1850 s onwards did Australia begin catching up with the two world leaders. However, while having overtaken Britain in the 1870 s, Australia had not reached a position of leadership since its PPPadjusted GDP per capita remained lower than the US.

One of the explanations for this finding lies with the relative cost of living used as the deflator throughout the period: up to the $1840 \mathrm{~s}$, Australia was 2.5-3 times more expensive for the working man than for the US working man, and it was still 50-70 percent higher in the decades following (see Table 6). A key driver behind the much costlier Australian consumption basket lies with the high cost of imports and colonial manufactures (soap, candles, clothes, lamp oil and low-quality colonial cheese), ${ }^{23}$ as well as house rents. Domestically made goods (and house

\footnotetext{
${ }^{22}$ For even earlier such comparative estimates, see Bairoch (1976), although he does not include Australia.

${ }^{23}$ While being self-sufficient in butter production since the 1840s, all Australian colonies remained net importers of cheese throughout the nineteenth century (Henzell 2007, p.114).
} 
structures) were expensive due to their labour-intensity and high wages driven by labour scarcity. Table 6 also shows a big drop in the cost of the basket in the 1860s, reflecting the end of a sustained period of price hikes caused by the gold rush of the $1850 \mathrm{~s}$. But the drop in relative cost of living persisted, presumably driven by the beginning of worldwide commodity price convergence with the integration of global markets - especially from the decline in transport costs along sea lanes and thus a drop in the cost of imported goods. Table 7 decomposes these price effects as they served to alter living costs in Australia over time. The table reports for tradables and non-tradables their changing prices weighted by their fixed quantities in the consumption basket, the product then taken as a ratio to the total cost of living. The figures rise for non-tradables (including beans, peas, meat, fuel and house rents) from 53.1\% in 1820 to $62.4 \%$ in 1870 ; that is, their relative prices rose and their share in total consumption was high enough to put an upward pressure on total living costs. This, of course, confirms the BalassaSamuelson effect. But was it less than similar effects taking place in other settler economies? To our knowledge, there are no such estimates in the literature for Canada, the US or even the UK, but it certainly seems likely to us given the initial economic isolation of Australia and, compared with the New World competition, the importance of flour in total imports. Indeed, the relative price of imported consumption goods fell over time, from $46.9 \%$ to $37.8 \%$ of total living costs, thus confirming our predictions of globalisation and world market integration. ${ }^{24}$

Finally, note the difference between the GDP per capita estimates presented in Table $\mathbf{5}$ where the United States is taken as unity. Using his econometric "short cut" approximation of current prices, Prados de la Escosura estimated PPP-adjusted GDP per capita for Australia as

\footnotetext{
${ }^{24}$ However, the biggest item among these imports was flour, which rose to 1840 before joining the secular decline. Also, note that Canada and the US produced wheat and exported flour to world market, while Australia did not.
} 
1.085 in the 1870s, a world leader even among the New World English-speaking regions. Using 1990 PPPs, Maddison estimated 1.340. Using our period-specific PPPs, we estimate 1.199, much closer to Prados de la Escosura than to Maddison, and still a world leadership result.

\section{Looking Ahead to the Late Nineteenth Century}

As highlighted by the McLean quote at the beginning of this paper, one of the most agreed upon views about Australian economic development is that it produced the highest living standards in the world sometime during the late nineteenth century. However, the literature is divided about the timing and magnitude of Australia's leadership, with diverging views stemming from the way in which living standards are measured and the evidence employed. Moreover, recent debate has cast doubt on the reliability of existing GDP PPP-1990 estimates, especially as we go farther back in time. Drawing on a novel dataset on commodity prices and wages we contribute to this debate by providing more accurate estimates of Australian living standards by using two different purchasing power parity adjusted measures -- welfare ratios and real GDP per capita. Our findings shed light on Australian standards of living back to the $1820 \mathrm{~s}$, a time when the reliability of the available comparative income estimates are especially limited. Moreover, by computing living standards at the colony level, we have provided a richer picture of Australian experience highlighting the existence of considerable differences across colonies. As such, our estimates offer a better understanding of Australia's comparative living standard performance.

Although in the half century up to 1870 labour productivity grew faster in Australia than in the United States, Great Britain and Western Europe, the resulting catch up growth of real earnings and living standards was driven equally by a steep decline in living costs relative to the 
competition. In the pre-globalisation 1820s, very high living costs, driven in large part by expensive imports, greatly moderated Australian labour scarcity as reflected in real earnings. And since the big cost of living gap between Australia and both Great Britain and the United States declined dramatically towards the end of our period, one is pushed to hypothesize that this process continued into the late nineteenth century as world globalisation deepened and intensified, especially where the "tyranny of distance" was most pronounced - in Australia. 


\section{References}

Primary Sources

$19^{\text {th }}$ Century House of Commons Sessional Papers: Statistical Tables relating to the Colonial and other Possessions of the United Kingdom, Parts I-XVII (1856-1881). Command Papers No: 2127; 2284; 2441; 2565; 2741; 2893; 3065; 4194-I; 3396; 3650; 3879; 4030-I; 4194-I; C.1038; C.2029; C.2867; C.4519.

\section{Secondary Sources}

Allen, R. C. (1994). "Real incomes in the English-speaking world, 1879-1913.” In G. Grantham and M. McKinnon (eds.), Labour Market Evolution: The Economic History of Market Integration, Wage Flexibility, and the Labour Relation (Routledge: London), pp.107-38.

Allen, R. C. (2009). The British Industrial Revolution in Global Perspective (Cambridge: Cambridge University Press).

Allen, R. C., Bassino, J-P., Ma, D., Moll-Murata, C., and van Zanden, J. L. (2001). "Wages, prices, and living standards in China, 1738-1925: in comparison with Europe, Japan, and India" Economic History Review, 64(1), pp. 8-38.

Allen, R. C., Murphy, T.E. and Schneider, E. B. (2012). "The Colonial Origins of Divergence in the Americas: A Labor Market Approach". Journal of Economic History 72, 4 (December): 863-94 and supplementary materials.

Arroyo Abad, L. (2014). "Failure to launch: Cost of living and living standards in Peru during the 19th century." Revista de Historia Economica-Journal of Iberian and Latin American Economic History 32.1 (2014): 47-76.

Bairoch, P. (1976). "Europe's Gross National Product: 1800-1975," Journal of European Economic History 5: 273-340. 
Barnard, J. (1856). Statistical account of Van Diemen's Land, from the date of its first occupation by the British nation in 1804 to the end of the year 1848. (Hobart: Tasmania Government Printer).

Baxter, D. R. (1868). National Income: The United Kingdom (London: Macmillan).

Blainey, G. (1966). The Tyranny of Distance: How Distance Shaped Australi's History. Melbourne: Sun Books.

Bowley, A. L. (1919): The Division of the Product of Industry: An Analysis of National Income Before the War (Oxford: Clarendon Press).

Boyer, G. R. (2016 ongoing). The Winding Road to the Welfare State: Economic Insecurity and Social Welfare Policy in Britain, 1840-1940. Manuscript.

Broadberry, S. and Irwin, D. (2007). "Lost Exceptionalism? Comparative Income and Productivity in Australia and the United Kingdom, 1861-1948," Economic Record, 83, $247-357$.

Butlin, M., R. Dixon, and P. J. Lloyd (2015). “Appendix: selected data series, 1800-2010.” In S. Ville and G. Withers (eds.), The Cambridge Economic History of Australia (Cambridge: Cambridge University Press), pp. 555-591.

Butlin, N. G. (1970). "Some perspectives of Australian economic development, 1890-1965." In C. Foster (ed.), Australian Economic Development in the Twentieth Century (Allen and Unwin: London), pp. 266-327.

Cashin, P. (1995a). "Economic Growth and Convergence Across the Seven Colonies of Australia: 1861-1991,” The Economic Record 71, 213 (June): 132-144.

Cashin, P. (1995b). "Real GDP in the seven colonies of Australasia: 1861-1991." Review of Income and Wealth 41.1: 19-39. 
Coghlan, T. A. (1918). Labour and Industry in Australia. Vols. I-III (Melbourne: Oxford University Press).

Gelman, J. and D. Santilli (2018) "Wages and standards of living in the 19th Century from a comparative perspective. Consumption basket, Bare Bone Basket and welfare ratio in Buenos Aires, 1825-1849." Investigaciones en Historia Económica, Madrid, in press.

Greasley, D. (2015). “Industrialising Australia's natural capital” In S. Ville and G. Withers (eds.), The Cambridge Economic History of Australia (Cambridge: Cambridge University Press), pp.150-177.

Greasley, D. and L. Oxley (2000). “Measuring New Zealand's GDP 1865-1933: a cointegrationbased approach," Review of Income and Wealth, 46(3), 351-368.

Greasley, D. and L. Oxley (2004). "Globalization and real wages in New Zealand 1873-1913," Explorations in Economic History 41: 26-47.

Greasley, D. and L. Oxley (2005). "Refrigeration and distribution: New Zealand land prices and real wages 1873-1939," Australian Economic History Review, 45,1, 23-44.

Haig, B. D. (1989). "International comparison of Australian GDP in the $19^{\text {th }}$ century." Review of Income and Wealth 35, 2 (June): 151-62.

Haig, B. D. (2008). "Real Product and Productivity of Industries since the Nineteenth Century: A Comment on 'Lost Exceptionalism’ by Broadberry and Irwin.” Economic Record 84, 267 (December): 511-4.

Henzell, T. Australian agriculture: its history and challenges. CSIRO publishing, 2007.

Keneley, M. (2015). “The service economy.” In S. Ville and G. Withers (eds.), The Cambridge Economic History of Australia (Cambridge: Cambridge University Press), pp. 373-394. 
Lindert, P. H. (2017). “Purchasing Power Disparity before 1914?” NBER Working Paper 22896. National Bureau of Economic Research, Cambridge, MA (December).

Lindert, P. H. and J. G. Williamson (2016). Unequal Gains: American Growth and Inequality since 1700 (Princeton, N.J.: Princeton University Press).

Maddison, A. (1995a). "Explaining the economic performance of nations, 1820-1989." In A. Maddison, Explaining the economic performance of nations: essays in time and space (Aldershot), pp. 91-132.

Maddison, A. (1995b). Monitoring the World Economy 1820-1992 (Paris: OECD).

Madsen, J. (2015). “Australian economic growth and its drivers since European settelment." In S. Ville and G. Withers (eds.), The Cambridge Economic History of Australia (Cambridge: Cambridge University Press), pp. 29-51.

Magee, G. B., L. Greyling, and G. Verhoef (2016). "South Africa in the Australian mirror: per capita real GDP in the Cape Colony, Natal, Victoria, and New South Wales, 1861-1909," Economic History Review 69, 3: 893-914.

McLean, I. W. (2007). “Why was Australia so rich?” Explorations in Economic History 44: 63556.

McLean, I. W. (2012). Why Australia Prospered: The Shifting Sources of Economic Growth. Princeton University Press.

Mulhall, M. (1892). The Dictionary of Statistics (London).

Panza, L. and Williamson, J. G. (2017). Australian Exceptionalism?: Inequality and Living Standards 1821-1871. CEPR Discussion Paper 11756, Centre for Economic Policy Research (January). 
Prados de la Escosura, L. (2000). "International Comparisons of Real Product, 1820-1990: An Alternative Data Set." Explorations in Economic History 37: 1-41.

Reynolds, H. (2012). History of Tasmania (Melbourne: Cambridge University Press).

Seltzer, A. (2015). “Labour, skills and migration.” In S. Ville and G. Withers (eds.), The Cambridge Economic History of Australia (Cambridge: Cambridge University Press), pp. $178-201$.

Shanahan, M. P. (2015). "Wealth and welfare.” In S. Ville and G. Withers (eds.), The Cambridge Economic History of Australia (Cambridge: Cambridge University Press), pp. 489-510.

Sinclair, W. A. (2009). Annual Estimates of Gross Domestic Product: Australian Colonies/States 1861-1976/77, Working Paper, Department of Economics, Monash University (September).

Thomas, M. (1991). "The evolution of inequality in Australia in the nineteenth century." In Y. S. Brenner and H. Kaelble (eds.), Income distribution in historical perspective (Cambridge: Cambridge University Press), pp. 149-173.

Williamson, J. G. (2012). ”Commodity Prices over Two Centuries: Trends, Volatility and Impact," Annual Review of Resource Economics 4: 185-207. 
Figure 1A: Australian colonies' welfare ratios (bare bone), 1820-1870.

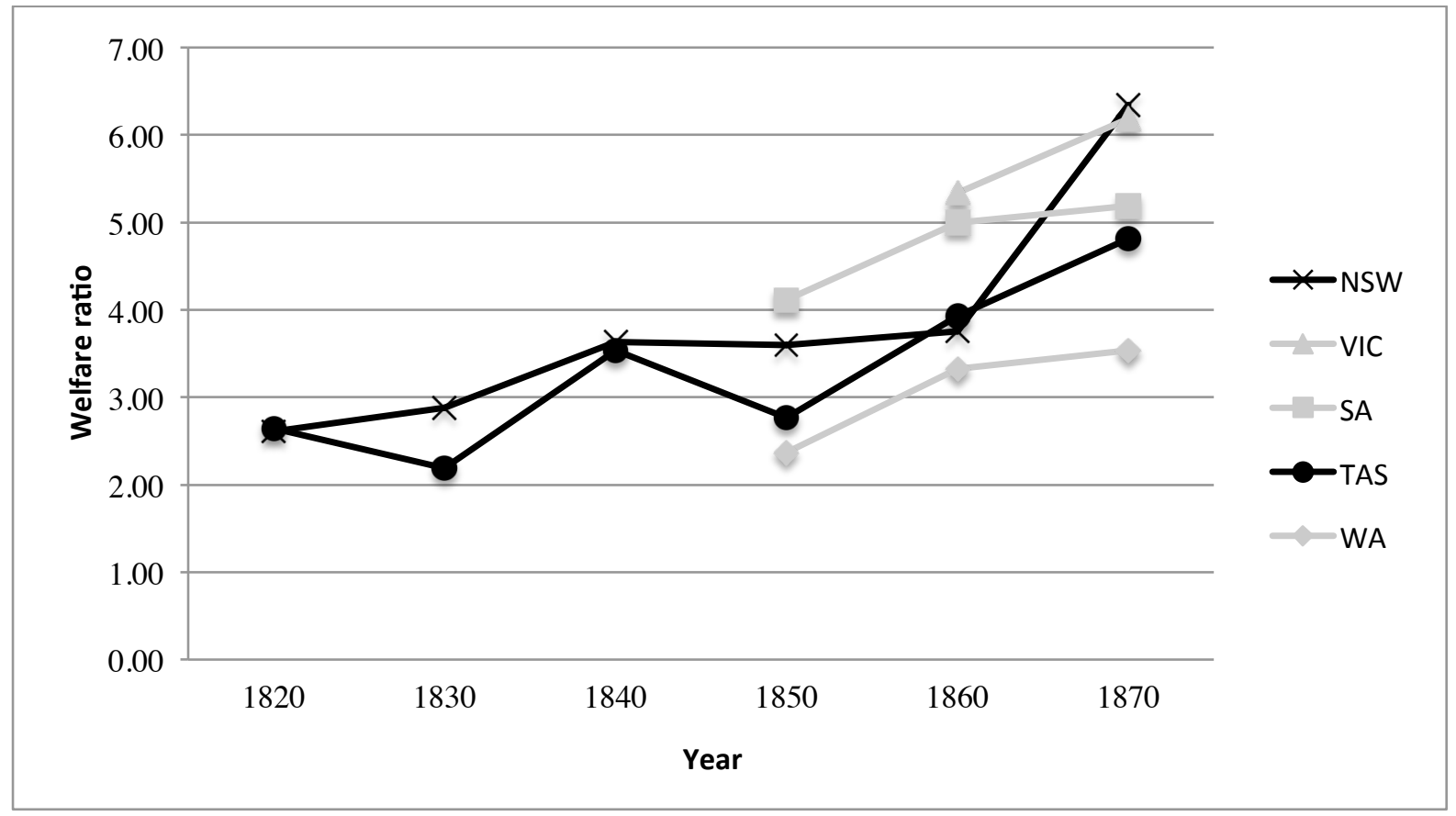

Figure 1B: Australian colonies' welfare ratios (respectable), 1820-1870.

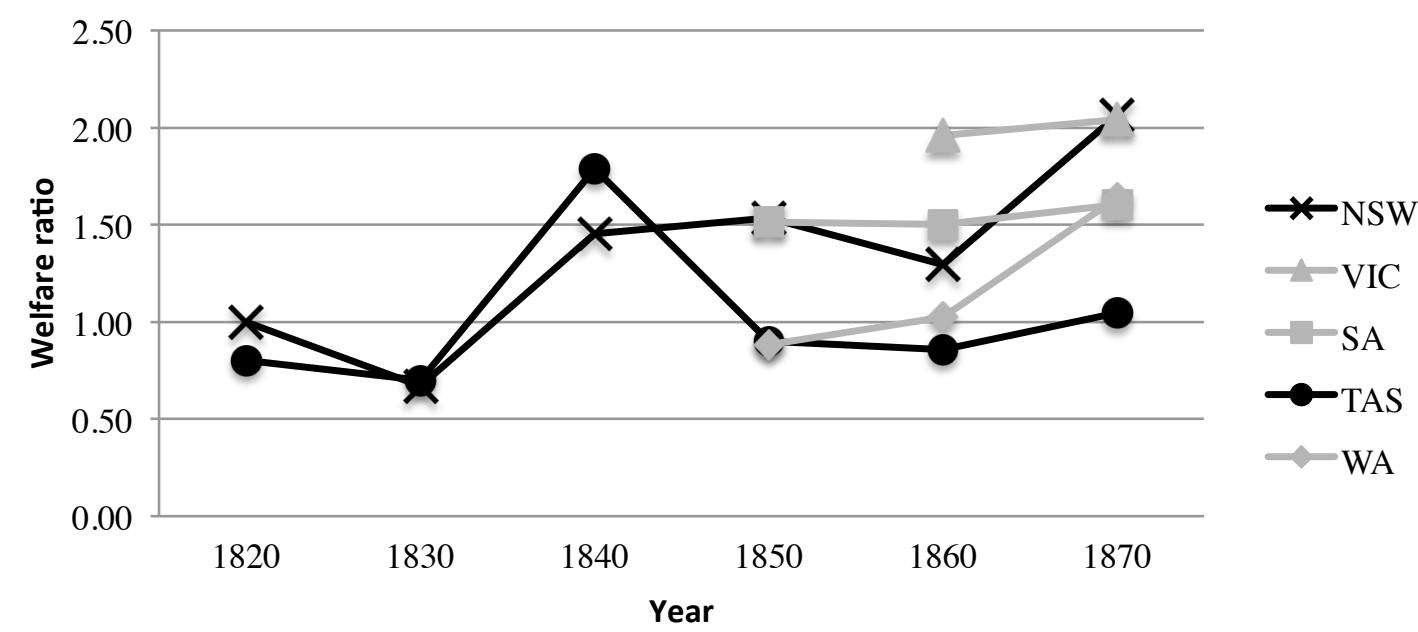

Sources: see text 
Table 1. Australian baskets at the bare-bones and respectable level

\begin{tabular}{lcccc}
\hline & \multicolumn{2}{c}{ Bare-bones basket } & \multicolumn{2}{c}{ Respectable basket } \\
\hline Goods & Quantity per year & Kcal per day & Quantity per year & Kcal per day \\
\hline Potatoes & $255 \mathrm{~kg}$ & 610 & $165 \mathrm{~kg}$ & 395 \\
Flour & $103 \mathrm{~kg}$ & 1040 & & \\
Bread & & & $110 \mathrm{~kg}$ & 711 \\
Sugar & & $16.5 \mathrm{~kg}$ & 171 \\
Milk & & $45 \mathrm{~kg}$ & 79 \\
Tea & & & $9.8 \mathrm{lb}$ & \\
Beans/peas & $20 \mathrm{~kg}$ & $40 \mathrm{~kg}$ & 370 \\
Meat & $10 \mathrm{~kg}$ & 187 & $60 \mathrm{~kg}$ & 408 \\
Butter & $1.5 \mathrm{~kg}$ & 68 & $2.6 \mathrm{~kg}$ & 104 \\
Cheese & & 30 & $2.6 \mathrm{~kg}$ & 54 \\
Eggs & & $52 \mathrm{each}$ & 11 \\
Rum & & $14.56 \mathrm{lt}$ & 118 \\
Soap & $1.3 \mathrm{~kg}$ & $2.6 \mathrm{~kg}$ & \\
Linen & $3 \mathrm{~m}$ & & $5 \mathrm{~m}$ & \\
Candles & $1.3 \mathrm{~kg}$ & $2.6 \mathrm{~kg}$ & \\
Lamp oil & $1.3 \mathrm{lt}$ & & $2.6 \mathrm{lt}$ & \\
Fuel & $2.0 \mathrm{M} \mathrm{BTU}$ & $5.0 \mathrm{M} \mathrm{BTU}$ & \\
Total & & & & 2,421 \\
\hline Source: Adapted from & & & & \\
\hline
\end{tabular}

Source: Adapted from Allen (2009) and Panza and Williamson (2017). 
Table 2: Australia's welfare ratios in comparative perspective, unskilled workers (using barebones basket)

\begin{tabular}{|c|c|c|c|c|c|c|}
\hline & 1820 & 1830 & 1840 & 1850 & 1860 & 1870 \\
\hline Sydney (NSW) & 2.61 & 2.88 & 3.63 & 3.60 & 3.76 & 6.34 \\
\hline Melbourne (VIC) & & & & & 5.34 & 6.18 \\
\hline Adelaide (SA) & & & & 4.11 & 5.00 & 5.19 \\
\hline Hobart (TAS) & 2.64 & 2.19 & 3.53 & 2.76 & 3.93 & 4.81 \\
\hline Perth (WA) & & & & 2.37 & 3.32 & 3.54 \\
\hline Australia & 2.62 & 2.64 & 3.61 & 3.55 & 4.67 & 5.99 \\
\hline London & 3.64 & 3.83 & 3.70 & 4.03 & 4.01 & 5.03 \\
\hline Boston (USA) & 6.03 & 6.56 & 7.00 & 5.89 & 5.66 & [8.32] \\
\hline Philadelphia (USA) & 8.95 & 7.67 & 9.50 & 7.85 & 7.51 & 11.03 \\
\hline$U S A$ & 7.49 & 7.12 & 8.25 & 6.87 & 6.59 & [9.68] \\
\hline Buenos Aires (ARG) & 3.28 & 1.77 & & 4.71 & & \\
\hline Santiago $(C H L)$ & & 1.08 & 1.65 & 0.97 & 1.30 & 1.08 \\
\hline $\operatorname{Lima}(P E R)$ & 0.95 & & & & & \\
\hline Mexico city $(M E X)$ & 1.85 & 4.18 & 4.07 & 4.07 & & \\
\hline Bogota $(C O L)$ & 1.87 & 2.84 & 2.78 & & & \\
\hline Potosi (PER) & & & 1.71 & & & \\
\hline
\end{tabular}

Sources: Bogota, Boston, Mexico City, Philadelphia, Santiago, Potosi and London are from Allen et al. (2012); Buenos Aires: Gelman and Santilli (2018). Lima from Arroyo Abad (2014). Australia: see text.

Notes: The Australian figures are decade averages (e.g. $1820=1820-29)$. United States is an unweighted average of Boston and Philadelphia; the 1870 figure for Boston is estimated assuming the same trends as Philadelphia across the 1860s. Australia is a population weighted average of the five towns. 
Table 3: Decomposing unskilled workers' welfare ratios (using bare-bones basket) by colony. NSW welfare ratio $=100$

\begin{tabular}{|c|c|c|c|c|c|c|}
\hline & 1820 & 1830 & 1840 & 1850 & 1860 & 1870 \\
\hline \multicolumn{7}{|l|}{ Sydney (NSW) } \\
\hline Cost of basket & 340.36 & 341.94 & 309.86 & 480.95 & 332.71 & 259.48 \\
\hline Annual income & 888 & 985 & 1125 & 1732.4 & 1250 & 1645.83 \\
\hline \multicolumn{7}{|l|}{ Melbourne (VIC) } \\
\hline Cost of basket & & & & & 316.26 & 257.14 \\
\hline Annual income & & & & & 1687.5 & 1590.28 \\
\hline Welfare ratio & & & & & 1.42 & 0.98 \\
\hline \multicolumn{7}{|l|}{ Adelaide (SA) } \\
\hline Cost of basket & & & & 418.22 & 311.27 & 301.00 \\
\hline Annual income & & & & 1718.8 & 1556.2 & 1562.50 \\
\hline Welfare ratio & & & & 1.14 & 1.33 & 0.82 \\
\hline \multicolumn{7}{|l|}{ Hobart (TAS) } \\
\hline Cost of basket & 360.5 & 370.79 & 318.32 & 505.22 & 286.46 & 259.88 \\
\hline Annual income & 952 & 812 & 1125 & 1395.8 & 1125 & 1250 \\
\hline Welfare ratio & 1.01 & 0.76 & 0.97 & 0.77 & 1.04 & 0.76 \\
\hline \multicolumn{7}{|l|}{ Perth (WA) } \\
\hline Cost of basket & & & & 482.26 & 373.00 & 387.00 \\
\hline Annual income & & & & 1142 & 1240 & 1369 \\
\hline Welfare ratio & & & & 0.66 & 0.88 & 0.56 \\
\hline
\end{tabular}

Sources: See text.

Notes: Both the cost of the basket and annual income are in shillings. 
Table 4: Comparing welfare ratios to real GDP per capita

\begin{tabular}{lcccc}
\hline & \multicolumn{2}{c}{ Welfare ratio } & \multicolumn{2}{c}{ GDP in PPP } \\
\hline 1820 & Free & Free \& convicts & Per capita & Per worker \\
1830 & 2.615 & 2.006 & 4.280 & 6.460 \\
1840 & 2.643 & 2.093 & 6.110 & 6.068 \\
1850 & 3.605 & 3.343 & 5.395 & 9.514 \\
1860 & 3.554 & 3.546 & 5.904 & 6.477 \\
1870 & 4.673 & 4.673 & 10.837 & 23.697 \\
\hline
\end{tabular}

Sources: Welfare ratios, see Table 2. GDP per capita, see Table 4. The (male and female) labour force data to compute GDP per worker are from colonial censuses, using geometric interpolation for missing years.

Notes: The welfare ratio figures are decade averages (e.g. $1820=1820-29$ ). 
Table 5: Comparative GDP per capita estimates for Australia, the United States and the United Kingdom 1820s-1870s (US=1), decade averages.

\begin{tabular}{|c|c|c|c|c|}
\hline & $\begin{array}{c}\text { PPP-adjusted shortcut } \\
\text { Prados }\end{array}$ & $\begin{array}{l}\text { PPP-1990 } \\
\text { Maddison }\end{array}$ & $\begin{array}{l}\text { Exchange } \\
\text { rate }\end{array}$ & $\begin{array}{c}\text { PPP-adjusted } \\
\text { This Study }\end{array}$ \\
\hline \multicolumn{5}{|l|}{$1820 \mathrm{~s}$} \\
\hline Australia & 1.098 & 1.316 & 1.361 & 0.439 \\
\hline United Kingdom & 0.985 & 1.421 & 1.228 & 0.862 \\
\hline \multicolumn{5}{|l|}{$1830 \mathrm{~s}$} \\
\hline Australia & 1.272 & na & 1.924 & 0.580 \\
\hline United Kingdom & 0.990 & 1.379 & 1.287 & 0.795 \\
\hline \multicolumn{5}{|l|}{ 1840s } \\
\hline Australia & 1.233 & na & 2.42 & 0.443 \\
\hline United Kingdom & 0.901 & 1.373 & 1.142 & 0.762 \\
\hline \multicolumn{5}{|l|}{$1850 \mathrm{~s}$} \\
\hline Australia & 1.200 & 1.822 & 1.540 & 0.434 \\
\hline Canada & 0.831 & 0.731 & 0.770 & na \\
\hline United Kingdom & 0.986 & 1.359 & 1.299 & 0.713 \\
\hline \multicolumn{5}{|l|}{$1860 s$} \\
\hline Australia & 1.217 & 1.741 & 2.219 & 0.747 \\
\hline Canada & 0.831 & 0.679 & 0.822 & na \\
\hline New Zealand & 1.111 & 1.632 & 2.899 & na \\
\hline United Kingdom & 0.988 & 1.374 & 1.150 & 0.669 \\
\hline \multicolumn{5}{|l|}{$1870 s$} \\
\hline Australia & 1.085 & 1.34 & 1.395 & 1.199 \\
\hline Canada & 0.784 & 0.63 & 0.619 & na \\
\hline New Zealand & 0.998 & 1.432 & 1.850 & na \\
\hline United Kingdom & 0.954 & 1.306 & 1.038 & 0.966 \\
\hline
\end{tabular}

Sources: Prados de la Escosura (2000); Maddison (1995a, 1995b) and exchange rates as reported in Prados de la Escosura (2000: Table 9, pp.24-5). This study's estimates are described in the text, as are the Prados "shortcut PPP" and the Maddison "1990 PPP". UK and US PPP-adjusted values are from Lindert (2017: Table 3) and Lindert and Williamson (2016:Table 10.1). 
Table 6: The Relative Costs of bare-bones consumer bundles in Australia, the United Kingdom and the United States 1820-1870 (US = 1).

\begin{tabular}{lcc}
\hline & Australia & United Kingdom \\
\hline $\mathbf{1 8 2 0}$ & 3.244 & 1.492 \\
$\mathbf{1 8 3 0}$ & 2.831 & 1.271 \\
$\mathbf{1 8 4 0}$ & 2.582 & 1.428 \\
$\mathbf{1 8 5 0}$ & 3.129 & 1.176 \\
$\mathbf{1 8 6 0}$ & 1.460 & 0.966 \\
$\mathbf{1 8 7 0}$ & 1.657 & 1.398 \\
\hline
\end{tabular}

Sources: The UK and US data underlie Figure 6, p. 6 in Lindert (2017). The Australian data are described in the text. 
Table 7: Share of the budget spent for each commodity included in the bare bone basket, Australian average, 1820s-1870s.

\begin{tabular}{lcccccc}
\hline & $\mathbf{1 8 2 0}$ & $\mathbf{1 8 3 0}$ & $\mathbf{1 8 4 0}$ & $\mathbf{1 8 5 0}$ & $\mathbf{1 8 6 0}$ & $\mathbf{1 8 7 0}$ \\
\hline $\begin{array}{l}\text { Total non } \\
\text { tradables }\end{array}$ & $\mathbf{5 3 . 1 \%}$ & $\mathbf{5 5 . 9 \%}$ & $\mathbf{5 5 . 4 \%}$ & $\mathbf{5 7 . 2 \%}$ & $\mathbf{6 2 . 2 \%}$ & $\mathbf{6 2 . 4 \%}$ \\
$\begin{array}{l}\text { Potatoes } \\
\text { Beans/peas }\end{array}$ & $34.2 \%$ & $35.3 \%$ & $35.0 \%$ & $36.9 \%$ & $38.0 \%$ & $30.8 \%$ \\
Meat & $5.7 \%$ & $5.3 \%$ & $6.3 \%$ & $6.0 \%$ & $6.8 \%$ & $6.6 \%$ \\
& $7.8 \%$ & $9.8 \%$ & $8.0 \%$ & $8.5 \%$ & $10.1 \%$ & $12.8 \%$ \\
Fuel & & & & & & \\
Rent & $0.4 \%$ & $0.4 \%$ & $1.1 \%$ & $0.9 \%$ & $1.0 \%$ & $2.5 \%$ \\
Total & $5.0 \%$ & $5.0 \%$ & $5.0 \%$ & $4.9 \%$ & $6.2 \%$ & $9.7 \%$ \\
tradables & $\mathbf{4 6 . 9 \%}$ & $\mathbf{4 4 . 1 \%}$ & $\mathbf{4 4 . 6 \%}$ & $\mathbf{4 2 . 8 \%}$ & $\mathbf{3 7 . 8 \%}$ & $\mathbf{3 7 . 6 \%}$ \\
Flour & $25.2 \%$ & $25.0 \%$ & $36.5 \%$ & $34.9 \%$ & $30.4 \%$ & $29.5 \%$ \\
Butter & $5.5 \%$ & $5.0 \%$ & $2.5 \%$ & $3.0 \%$ & $3.1 \%$ & $3.3 \%$ \\
Soap & $4.0 \%$ & $3.9 \%$ & $0.9 \%$ & $1.0 \%$ & $0.9 \%$ & $0.8 \%$ \\
Linen & $5.5 \%$ & $4.0 \%$ & $1.8 \%$ & $1.2 \%$ & $0.8 \%$ & $0.7 \%$ \\
Candles & $4.8 \%$ & $4.3 \%$ & $1.8 \%$ & $1.5 \%$ & $1.3 \%$ & $1.6 \%$ \\
Lamp oil & $1.5 \%$ & $1.5 \%$ & $1.4 \%$ & $1.3 \%$ & $1.3 \%$ & $1.3 \%$ \\
\hline Sources: Sex & & & & & \\
\hline
\end{tabular}

Sources: See text. 